\title{
The national and cultural peculiarities of stereotyped precedent names (A case study of the Kazakh, Russian, and English languages)
}

\author{
Aigul Murzinova - Altynay Tymbolova - Kalima Yelshibaeva - Gulmira \\ Abdirassilova - Ainur Kushkimbayeva - Mukhtar Mirov
}

DOI: 10.18355/XL.2018.11.02.55

\begin{abstract}
The relevance of the research is determined by the task to consider the century-long stereotypes embodied in the collective consciousness of the people in terms of the national and cultural linguistic aspect, to study this phenomenon by means of comparative analysis of stereotyped precedent names in different languages and reveal the specificity of the national mentality and culture of different nations. The objective of this article is to identify national and cultural peculiarities of stereotyped precedent names as a case study of the Kazakh, Russian, and English languages. The research is aimed at establishing a connection between language and culture in the content of precedent names and their role in the formation of national and cultural stereotypes. They make the linguistic fabric of fiction works and are an important means of revealing the content of a literary text. Methods of the research: generalization and analysis are the leading methods employed by the authors while studying stereotyped precedent names in different languages. The research results: The stereotyped precedent names were analyzed on a national and cultural basis, comparison of the national and cultural features of stereotyped precedent names in the Kazakh, Russian and English languages was made, and the identified stereotyped precedent names were classified. The significance of the study: a comparative analysis of precedent names reveals the specifics of the national mentality and culture of the people using these names and helps understand connotations of national and cultural components stereotyped precedent names in foreign languages. The research findings can be useful for linguists dealing with cross-cultural communication, language teachers, students and people interested in making acquaintance with foreign culture.
\end{abstract}

Key words: national-cultural stereotype, behavior stereotype, stereotype image, national mentality, value, world's language image, national linguistic cognition

\section{Introduction}

Nowadays, the growing of interest to foreign national languages and culture, and international relations between nations is one of the most important necessities that appeared according to the time requests. In this regard, much attention is paid to the function of the cognoscibility of the national language and the archive, which conveys national cultural values from generation to generation. Studies of recent years are aimed at determining the original environment of the language that emerged from the national mentality and set the task before linguists to consider the stereotypes embodied in the collective consciousness of the people for many centuries from the point of view of the national and cultural linguistic aspect.

The well-known names of fiction characters, the names of historical figures, people who distinguished themselves in various fields of science and culture are considered precedent ones. Precedent names are able to encode, store and update cultural information, they are used to express subjective evaluation, to convey emotional state, express and consolidate ethical and other norms of behavior. Denotation to the proper name is always preserved in the precedent name. Precedent names accumulate ethical norms associated with the images personified by them; they determine the model of

XLinguae, Volume 11, Issue 2, April 2018, ISSN 1337-8384, eISSN 2453-711X 
the behavior of the linguistic cultural community members. Viewed in this way, it is important to understand how the precedent name, being the phenomena of linguistic and cognitive plans, participate in shaping the people's attitude to the reality and how they fix the material and spiritual values of this linguistic, cultural community. Precedent names have distinctive features, attributes that distinguish one precedent name from another.

It seems reasonable to consider the notion of "stereotype" (from Greek stereos volume, typos - imprint). Information giving insight into the problems of "stereotype" can be found in the works of R. Ermers (2017), Y.E. Prokhorov (2008), O.N. Frolova (2009), K.N. Smagulova (1998).

According to scholars, stereotypes are standard images of a particular social phenomenon or object (Ermers, 2017), some fragments in the conceptual world outlook of national cultural situations, formed in connection with a certain condition or phenomenon (Prokhorov, 2008), a simple image in consciousness about a true life, widespread in the ordinary use, cognition of a particular thing or phenomenon, situation or action, personality or society (Frolova, 2009), a formal manifestation of the national linguistic image of a single ethno-cultural community (Smagulova, 1998), stereotype is some 'representation' of a fragment of the surrounding reality, a fixed mental 'picture', which is the result of reflection in the consciousness of the personality of a 'typical' fragment of the real world, an invariant of a certain section of the picture of the world, a fragment of the conceptual world picture, sustainable national cultural concept of mental 'picture', thing or situation (Almetova, Pirnazarova, 2014).

When generalizing the above definitions, it can be said that the stereotype is a shackle formed through the national cultural life of a certain people, both in the mental form of national cultural values that have passed through the consciousness of generations from century to century and in the form of a verbalization personality. To be precise, it is a means of mutual relation, which in its way shows the whole nature of the people, that is, its life, the spiritual world, national colors, worldview, customs and traditions, economy and others.

Stereotypes are under study and investigated based on linguistic material from one or several languages. Stereotypes appeared of great help in description and analysis of various linguistic data. The notion of stereotype has been under research in such linguistic branches as lexicography, semantics, cognitive linguistics, etc. The studies investigating stereotypes deal with their verbal representation, linguistic background, and the method according to which language reproduces patterns of thought (Bril'ova et al., 2004; Houghton, 2014; Ladegaard, 2011).

Many works analyzing linguistic features of stereotypes pay attention to language facts in their relation to cultural aspects. Among the most studied spheres are media and social advertising. For instance, Russian stereotypes in connection to fathers' rights and duties are discussed from the point of view of basic stereotypes, metaphorical models, specifics of representation of fathers in media and social advertisements. Conclusions are made about the inconsistency of models of fatherhood translated, on the one hand, in the media, and on the other - in social advertising (Issers, 2017).

The notion of stereotype is found in the studies based on dictionary entries. There are many cultural stereotypes associated with gender. The analysis of the diverse material presented in a dictionary helps answer the questions about the representation of the two sexes in a language, whether these representations are accurate or biased, if the changes in a society are taken into considerations in the dictionary corpus and how stereotypes are reflected in this layer of vocabulary (Tenorio, 2000).

Research findings grounded on anthroponyms deserve special attention. It is explained by the role personal names perform in connection with both linguistic and cultural levels (Rembiszewska, 2010). Onomastic layer of vocabulary, especially that 
presenting multiethnic and multicultural regions, helps reveal historical awareness, sociolinguistic setting, national stereotypes and system of values (Rembiszewska, 2010).

The study of stereotypes is also closely connected with the notion of precedence.

According to I.S. Bril'ova et al. (2004) and others the precedent phenomena include statements, names, texts and situations that are well known to all representatives of the national linguistic and cultural community, are relevant in the cognitive aspect and often reproduced in the speech of representatives of one or another linguo-cultural community (Gudkov, 2004; Krasnykh, 2003).

As well as stereotypes, precedent phenomena are widely spread in the mass media discourse (Orlova, Kabankov, 2015; 2017; Ibrahim, Darwish, 2013; Shchuklina, 2017). It is revealing that "the precedent world is understood as an evolving system of discursive reactions of an unlimited number of actors to the stimulus of precedence"

(Orlova, Kabankov, 2017). Media discourse is characterized by the use of transformations of precedent phenomena. The authors argue that it "indicates the relevance of the precedent statement, its ability to respond flexibly to the context", on the one hand, "but leads to a "blurring" of the canonical structure", on the other (Bogoyavlenskaya, Nakhimova, Chudinov, 2016). Transformations of precedent units can be traced in other styles, for instance, scientific and religious texts (Budaev, Chudnov, 2017; Golubeva, 2016; 2017).

Another type of discourse which is broadly presented nowadays is the Internet discourse. In it there exist precedent phenomena that acquired the status of units of influence as a result of the growing socio-cultural relevance of certain media concepts (Orlova, 2013). Such units have a forceful regulative potential, i. e. the ability to encourage the linguistic personality not only to "implicit but also to explicit communicative-reflexive activity as a reaction to the regulative impulse" created by precedent phenomena (Orlova, Kabankov, 2017). Chat-communication is related to the Internet discourse. It is also worthy of consideration in the context of precedent language units. In particular, strong attention is focused on features of inclusion of precedent texts in language game in view of specifics of chat-communication (Gritsenko, 2009).

Corpus analysis similarly presents rich material for the study of the phenomenon of precedence as a means of conceptualizing events in a language (Bogoyavlenskaya, Nakhimova, Chudinov, 2016; Nagornaya, 2017; Yurina, Borovkova, 2015).

A rich source of precedent units is represented by fiction. Scholars study the principal types of precedent phenomena taking into account the possibilities of their transformations in the text under analysis (Raspaeva, 2017).

The survey of scientific research dedicated to the study of such phenomena as language stereotypes and precedent units reveal that these phenomena are investigated from the point of view of their semantic features, their relation to the areas of cultural knowledge, their cultural specificity, and selectivity. These studies are based both on the material of one or several languages (Ibrahim, Darwish, 2013).

The topicality of these phenomena is proved by the fact of covering a wide range of discourses in research. The corpus data are under investigation as well.

\section{Materials and Methods}

National-cultural stereotypes are based on repetitive things and situations that happen in people's daily life, and national-cultural values (proverbs and sayings, legends and stories, poems and croons, faith and religion, cultural designations). We can relate the precedent names to their number, as the data on the spiritual world and the national cultural life of the nation are reflected in precedent names. They perform the function of symbols, stable comparisons, metaphors and other expressive means in the form of a national-cultural code. It is also considered a socio-cultural marked unit used in the

XLinguae, Volume 11, Issue 2, April 2018, ISSN 1337-8384, eISSN 2453-711X 
form of small normative associations that are understandable for each ethno-cultural community. It is also proved by the opinions of linguists and scholars. For example, T.N. Kondratieva (1983) gives her definition in the work Metamorphoses of one's own name: "own name is the most concrete and at the same time the most abstract category, which makes it possible to trace not only the history of the people, its worldview, the history of the word, but also the transformation of a specific nominal value into a common concept, into an image, into a symbol". According to R.Y. Shebalov (2004), "the onomastic stereotype is a relatively stable, 'image' of the name fixed in the linguistic consciousness, standard code for interpreting the name as a sign bearing socio and ethno-cultural information about its potential carrier". In the opinion of F.M. Ashimhanova (2007), "precedent names play an important role in our culture, literature, history and reveal the content of the ethno-cultural and social aspects of anthroponyms". The authors examined the statements of these linguistic researchers and decided that it will be correct to analyze the stereotypes on a national and cultural basis in order to compare the national and cultural characteristics of stereotyped precedent names in Kazakh, Russian and English languages. That is why this research was aimed at considering stereotyped precedent names. They can be conditionally divided into four types: a) stereotyped precedent names on the basis of myths and legends; b) stereotyped precedent names on the basis of fairy tales, poems and chanting; c) stereotyped precedent names on the basis of historical data; d) stereotyped precedent names on the basis of fiction works.

\section{Results and Discussion}

\subsection{Stereotyped precedent names based on myths and legends}

The following phraseostereotypes can be found in Kazakh according to stereotyped precedent names on the basis of myths and legends: "One of forty quests - Kydyr", "Wherever you go, Korkyt's grave is everywhere", "Water's owner - Suleimen", "Suleimen also poured water", "to be as sad as AsanKaigi", and others. Their main content can be seen by traces of the ancient world of our people. To be precise, Kydyr is a stereotype in the image of a guardian angel, which helps travelers, a holy wayfarer giving people well-being, a guest from God. The following examples can be evidence of this: "Bright way to you if you go trot, let Kydyr be your companion!", "Let Kydyr give wealth to this bright house!"(Turlybaeva, 2010). "It is said that Kydyr is one of forty guests. The one who came to your house as Kydyr is the firstborn of Zhakan, Toxaba Myrza..." (Magayin, 2004).

Korkyt is the grandfather of the great kui (national music) in the traditional worldview of the Kazakh people, the owner of a noble kobyz (national musical instrument of the Kazakh people), a stereotype associated in the form of a wise predictor who has gone around the globe and sought the meaning of eternal life. And phraseostereotype "Wherever you go, Korkyt's grave is everywhere" means figurative sense such as 'difficulties, obstacles, failures'. This is probably the reason for the 'grave' lexeme to cause negative connotations. There is an example from social profiles according to this: "There is not a Korkyt's grave everywhere, but there is PR. The clothes you have, the meal you eat, and everything is advertisement" (Ardak, 2014). Frequent repetition of PR in everyday life is the same as that seen to Korkyt in the legendary network, its bad sides are reflected in the negative connotation.

Suleimen is a son of Dayt prophet who possesses 99 miracles by the command of Allah. He is considered as a water ruler who lived for thousand years in the traditional collective consciousness of the Kazakh people. The final cultural content of the above-mentioned phraseological stereotypes, based on legend, provides information about the traditions of the hospitality and meeting guests, along with the religious consciousness of our people. For example, phraseostereotype "Suleimen also poured water" talks about the ceremony of 'pouring water' in the courtesy of welcoming guests. More precisely, the owner of the house holds the metal cylinder with a 
handkerchief and gives it to his son, who pours water into the hands of the guest. The meaning of this dictum lies in the well-established principle of goodwill, courtesy, respect for each other, which is expressed in the saying of the Kazakh people "If you respect the guest, then God respects you". The phraseostereotype "Suleimen, the Water's owner" literally means 'religious' and then 'river, lake, sea', 'seaman, fisher, swimmer' and other similar variables. For example, "Suleimen, the Water's owner, has come out of its channel and made the people lurid".

Asan Kaigi is the only wise person of the Great Steppe, great thinker, mourning its grief and seeing its needs, narrator predictor, who sought life in peace and harmony, heaven on earth. There are national-cultural stereotype images in the Kazakh language, made through this stereotyped reflection and kept in the nation's memory, like 'a man of woe', 'the person who thinks about the needs of people', 'genius' and phraseostereotype 'to be sad as Asan Kaigi giving the meanings 'worry, discouragement, losing hope, frustration'.

The anthroponyms used in religious legends and myths like "Nikola", "Foma" and others can be related to stereotyped precedent names in Russian. For example, Nikola has a special value in the Russian people's religious consciousness and traditional culture. He is stereotyped as a saint that protects grain and arable lands from natural disasters, provides dignity and abundance to people, and saves them from various dangers. We can see it from the contents of such paremias as "На поле Никола общий бог" (Nicola is a common god on the field), "Кинул кафтан на дороге святой Никола побереги!" (I threw off the caftan on the road - Saint Nikola, take care of it!), "Бог на дорогу, Никола в nуть!" (God takes to the road, Nicolas sets off) (Chulkov, Polyakova, 1988) and others.

Foma (Thomas) is one of the twelve disciples of Jesus Christ in the Christian religion. His name is associated with someone who does not trust anybody or anything in the traditional world outlook of the Russian people. In this connection we can note such stereotyped phrases and paremias as "Фома неверующий” (Thomas, the eternal doubter), "Ври тому, кто не знает Фому, а я брат ему” (Lie to those who do not know Thomas, but I'm his brother), (Chulkov, Polyakova, 1988) and others. The Gospel Story was the basis to the formation of this kind of notion stored in the people's memory. This is stated in the phraseological dictionary of the Russian language: "Thomas, the eternal doubter (about a man who is hard to make believe something). Turnover came from the Gospel. One of the apostles, Foma, when he was told about the resurrection of the crucified Christ, declared: "Unless I see the nailmarks in Hishands, and put my finger where the nails have been, and put my hand into His side, I will never believe"(Bystrova, Shansky, 2007).

Anthroponyms in English Janus, Lucullen form precedent names. For example, Janus is a two-headed god in the ancient Roman mythology, whereas Lucullen is a prestigious person who has organized a festive cuisine in the ancient Roman legend, with wealth and richness. In connection with this, there is a constant analogue of "like Janus" in English and the phrase "Luculléanbanguet", or "Lucullean feast" (Krasnykh, 2012). In their cultural connotation, Janus is portrayed as hypocrisy and haughtiness, and Lucullen (Luke) is a symbol of richness and gentleness.

Features of national-cultural stereotyped precedent names in Kazakh, Russian and English are distinguished as follows: 
Table 1: Stereotyped precedent names based on myths and legends in Kazakh

\begin{tabular}{|c|c|c|c|}
\hline \multicolumn{4}{|c|}{ The national linguistic consciousness of the Kazakh people } \\
\hline Kydyr & Korkyt & Suleimen & Asan Kaigi \\
\hline $\begin{array}{l}\text { stereotypical } \\
\text { thinking: } \\
\text { religious, mythical } \\
\text { person- social } \\
\text { stereotype }\end{array}$ & $\begin{array}{l}\text { stereotypical } \\
\text { thinking: } \\
\text { religious, } \\
\text { mythical person- } \\
\text { social stereotype }\end{array}$ & $\begin{array}{l}\text { stereotypical } \\
\text { thinking: } \\
\text { religious, mythical } \\
\text { person - social } \\
\text { stereotype }\end{array}$ & $\begin{array}{l}\text { stereotypical } \\
\text { thinking: } \\
\text { legend person } \\
\text { - social stereotype }\end{array}$ \\
\hline $\begin{array}{c}\text { stereotypical } \\
\text { perception: wealth, } \\
\text { abundance, happiness, } \\
\text { poultry maker, } \\
\text { travelling quest - } \\
\text { national-cultural } \\
\text { stereotype image }\end{array}$ & $\begin{array}{l}\text { stereotypical } \\
\text { perception: } \\
\text { a seeker of } \\
\text { eternal life - } \\
\text { national-cultural } \\
\text { stereotype image }\end{array}$ & $\begin{array}{c}\text { stereotypical } \\
\text { perception: } \\
\text { water's owner - } \\
\text { national-cultural } \\
\text { stereotype image }\end{array}$ & $\begin{array}{c}\text { stereotypical } \\
\text { perception: } \\
\text { a man of woe, nervous } \\
\text { - national-cultural } \\
\text { stereotype image }\end{array}$ \\
\hline $\begin{array}{l}\text { stereotyped } \\
\text { cognition: } \\
\text { religious beliefs } \\
\text { stereotype }\end{array}$ & $\begin{array}{c}\text { stereotyped } \\
\text { cognition: } \\
\text { grandfather of } \\
\text { kobiz (a national } \\
\text { musical } \\
\text { instrument of the } \\
\text { Kazakh people), } \\
\text { the great kuishi (a } \\
\text { composer)- } \\
\text { social-cultural } \\
\text { stereotype } \\
\end{array}$ & $\begin{array}{l}\text { stereotyped } \\
\text { cognition: } \\
\text { religious beliefs } \\
\text { stereotype }\end{array}$ & $\begin{array}{c}\text { stereotyped } \\
\text { cognition: } \\
\text { a seeker of heaven, } \\
\text { wise, zhirau (a } \\
\text { philosopher, poet, } \\
\text { composer of the } \\
\text { Kazakh people) - } \\
\text { social-cultural } \\
\text { stereotype }\end{array}$ \\
\hline
\end{tabular}

Table 2: Stereotyped precedent names based on myths and legends in Russian

\begin{tabular}{|c|c|}
\hline \multicolumn{2}{|c|}{ The national linguistic consciousness of the Russian people } \\
\hline Nikola & Foma (Thomas) \\
\hline $\begin{array}{c}\text { stereotypical thinking: } \\
\text { religious, mythical person - social } \\
\text { stereotype }\end{array}$ & $\begin{array}{c}\text { stereotypical thinking: } \\
\text { religious person - social stereotype }\end{array}$ \\
\hline $\begin{array}{c}\text { stereotypical perception: } \\
\text { the landowner, the owner of the fields, and } \\
\text { of the grain - national-cultural stereotype } \\
\text { image }\end{array}$ & $\begin{array}{c}\text { stereotypical perception: } \\
\text { a person who does not trust anybody or } \\
\text { anything - national-cultural stereotype image }\end{array}$ \\
\hline $\begin{array}{c}\text { stereotyped cognition: } \\
\text { religious beliefs stereotype }\end{array}$ & $\begin{array}{c}\text { stereotyped cognition: } \\
\text { behavior stereotype }\end{array}$ \\
\hline
\end{tabular}

Table 3: Stereotyped precedent names based on myths and legends in English

\begin{tabular}{|c|c|}
\hline \multicolumn{2}{|c|}{ The national linguistic consciousness of the English people } \\
\hline Janus & Lucullean \\
\hline stereotypical thinking: & stereotypical thinking: \\
mythical person - social stereotype & legend person - social stereotype \\
\hline $\begin{array}{c}\text { stereotypical perception: } \\
\text { hypocritical, haughty, proud - national- } \\
\text { cultural stereotype image }\end{array}$ & $\begin{array}{c}\text { stereotypical perception: } \\
\text { stereotyped cognition: } \\
\text { wealth, abundance, and prosperity - national- } \\
\text { cultural stereotype-symbol }\end{array}$ \\
\hline $\begin{array}{c}\text { a two-headed god who governs the past and } \\
\text { the future - religious beliefs stereotype }\end{array}$ & stereotyped cognition: \\
\end{tabular}

\subsection{Stereotyped precedent names based on fairy tales}

According to stereotyped precedent names on the basis of fairy tales, poems and chanting, there are established comparisons and set phrases in the Kazakh language: “шық бермес Шызайбай” (greedy man Shygaibai), "Қарынбайдай құаныпезер” (merciless man Karynbai), "Қарынбай құнша мал жиса да, көзі тоймайды”" (а man (Karynbai) no matter how much cattle he has collected, but still, it is not enough 
for him), “Aтымтайдай жомарт” (generous man Atymtai), “Алдар көседей айлакер" (sly like Aldar Kose), "Қыз Жібек пен Төлегендей” (lovers like Kyz Zhibek and Tolegen), “Қозы Көрпешпен Баян сұлудай” (lovers like Kozi Korpesh and Bayan sulu), and others. In the following linguocultural units there are notions that are considered stereotyped reference images in the national consciousness; Shygaibai means a great deal of greed, Karynbai denotes philistinism and insatiability, Atimtai is generous and not mean, AldarKose is resourcefulness and cunning, Kiz Zhibek and Tolegen, Kozi Korpesh and Bayan sulu personify amorousness and love. For example, "Three people digging a well spent the night in the house of Barhan and drank hot tea in the days and evenings. At first, they guarded the house of Seyitkul but stopped following him, as he looked at them disapprovingly. Even then they talked about him grumbling, "he is jealous of his wife, because she is young, he is a greedy man like Shygaibai"(Bokeev, 1990).

"There are many soulless Karynbais, there are so little generous Atimtais" (Kopeiuly, 2010).

"Haven't Zhanaidar and Bopai been in love like KoziKorpesh and Bayan sulu? But Kasim tore (the title of aristocrat of the Kazakh people) did not let Bopai stay with Zhanaidar, because he was not a rich man" (Esenberlin, 2005).

"They look at each other with such warmth and kindness. They are... in love with each other like Kiz Zhibek and Tolegen” (Magayin, 2004).

There are national-cultural stereotype images made through Russian national fairy tales and poems: "Аника-воин” (Anika the Warrior), "Аника-войн сидит да воюет" (Anika the warrior is sitting and fighting), "Иванушка-Дурачок” (Ivan the Fool; simpleton Ivanushka), "Yетеlya", "Мели, Емеля, твоя неделя" (Talk nonsense, Yemelya, go on with your idle talk!), (Chulkov, Polyakova, 1988) and others. They have different cultural connotations in the linguistic consciousness of the Russian people. For example, Anika refers to the standard image of hooligans, bully, a braggart, Ivanushka and Yemelya are typical images of a confiding, stupid, lazy, but lucky person.

Anthroponyms of "Jack" and "Jill" are the national and cultural gender stereotypes of the English people in the composition of linguocultural units - "a good Jack makes a good Jill", "Jack of all trades", "All work and no play makes Jack a dull boy" which are widely used in the English language (Bogoyavlenskaya, Nakhimova, Chudinov, 2016; Simpson \&Speake, 2008). The creation of such a stereotype was based on a popular fairy tale about Jack who was talented in everything.

The national-cultural features of stereotyped precedent names in Kazakh, Russian and English can be found in the following tables.

Table4: Stereotyped precedent names on the basis of Kazakh fairy tales

\begin{tabular}{|c|c|c|c|c|}
\hline \multicolumn{5}{|c|}{ The national linguistic consciousness of the Kazakh people } \\
\hline Shygaibai & Karynbai & Atimtai & Aldar Kose & $\begin{array}{c}\text { Kyz Zhibek and } \\
\text { Tolegen, Kozi } \\
\text { Korpesh and } \\
\text { Baiansulu }\end{array}$ \\
\hline $\begin{array}{l}\text { stereotypical } \\
\text { thinking: } \\
\text { fairy tale } \\
\text { character- } \\
\text { social } \\
\text { stereotype }\end{array}$ & $\begin{array}{l}\text { stereotypical } \\
\text { thinking: } \\
\text { character in } \\
\text { poems- social } \\
\text { stereotype }\end{array}$ & $\begin{array}{l}\text { stereotypical } \\
\text { thinking: } \\
\text { fairy tale } \\
\text { character- } \\
\text { social } \\
\text { stereotype }\end{array}$ & $\begin{array}{l}\text { stereotypical } \\
\text { thinking: } \\
\text { fairy tale } \\
\text { character- } \\
\text { social } \\
\text { stereotype }\end{array}$ & $\begin{array}{l}\text { stereotypical } \\
\text { thinking: } \\
\text { character in } \\
\text { poems - social } \\
\text { stereotype }\end{array}$ \\
\hline
\end{tabular}

XLinguae, Volume 11, Issue 2, April 2018, ISSN 1337-8384, eISSN 2453-711X 


\begin{tabular}{|c|c|c|c|c|}
\hline $\begin{array}{l}\text { stereotypical } \\
\text { perception: } \\
\text { rich, mean, } \\
\text { greedy person } \\
\text { - national- } \\
\text { cultural } \\
\text { stereotype } \\
\text { image }\end{array}$ & $\begin{array}{l}\text { stereotypical } \\
\text { perception: } \\
\text { haughty, } \\
\text { snobby, miser, } \\
\text { greedy - } \\
\text { national-cultural } \\
\text { stereotype } \\
\text { image }\end{array}$ & $\begin{array}{l}\text { stereotypical } \\
\text { perception: } \\
\text { generous, } \\
\text { lavish, with } \\
\text { spiritual } \\
\text { wealth, clean- } \\
\text { hearted - } \\
\text { national- } \\
\text { cultural } \\
\text { stereotype } \\
\text { image }\end{array}$ & $\begin{array}{l}\text { stereotypical } \\
\text { perception: } \\
\text { sly, cunning - } \\
\text { national-cultural } \\
\text { stereotype } \\
\text { image }\end{array}$ & $\begin{array}{c}\text { stereotypical } \\
\text { perception: } \\
\text { two lovers - } \\
\text { national-cultural } \\
\text { stereotype image }\end{array}$ \\
\hline $\begin{array}{l}\text { stereotyped } \\
\text { cognition: } \\
\text { social and } \\
\text { cultural } \\
\text { behavior } \\
\text { stereotype }\end{array}$ & $\begin{array}{l}\text { stereotyped } \\
\text { cognition: } \\
\text { social and } \\
\text { cultural } \\
\text { behavior } \\
\text { stereotype }\end{array}$ & $\begin{array}{l}\text { stereotyped } \\
\text { cognition: } \\
\text { social and } \\
\text { cultural } \\
\text { behavior } \\
\text { stereotype }\end{array}$ & $\begin{array}{l}\text { stereotyped } \\
\text { cognition: } \\
\text { behavior } \\
\text { stereotype }\end{array}$ & $\begin{array}{l}\text { stereotyped } \\
\text { cognition: } \\
\text { love, falling in } \\
\text { love, friendship }- \\
\text { national-cultural } \\
\text { emotive } \\
\text { stereotypes }\end{array}$ \\
\hline
\end{tabular}

Table5: Stereotyped precedent names on the basis of Russian fairy tales

\begin{tabular}{|c|c|c|}
\hline \multicolumn{2}{|c|}{ The national linguistic consciousness of the Russian people } \\
\hline Anika & Ivanushka & Yemelya \\
\hline $\begin{array}{c}\text { stereotypical thinking: } \\
\text { character in poems- social } \\
\text { stereotype }\end{array}$ & $\begin{array}{c}\text { stereotypical thinking: } \\
\text { fairy tale character- social } \\
\text { stereotype }\end{array}$ & $\begin{array}{c}\text { stereotypical thinking: } \\
\text { fairy tale character- social } \\
\text { stereotype }\end{array}$ \\
\hline $\begin{array}{c}\text { stereotypical perception: } \\
\text { hooligans, bully, a } \\
\text { braggart, coward - } \\
\text { national-cultural } \\
\text { stereotype image }\end{array}$ & $\begin{array}{c}\text { stereotypical perception: } \\
\text { naive, lucky, confiding - } \\
\text { national-cultural stereotype } \\
\text { image }\end{array}$ & $\begin{array}{c}\text { stereotypical perception: } \\
\text { stupid, lazy- national-cultural } \\
\text { stereotype image }\end{array}$ \\
\hline $\begin{array}{c}\text { stereotyped cognition: } \\
\text { social and cultural } \\
\text { behavior stereotype }\end{array}$ & $\begin{array}{c}\text { stereotyped cognition: } \\
\text { behavior stereotype }\end{array}$ & $\begin{array}{c}\text { stereotyped cognition: } \\
\text { behavior stereotype }\end{array}$ \\
\hline
\end{tabular}

Table6: Stereotyped precedent names on the basis of English fairy tales

\begin{tabular}{|c|c|}
\hline \multicolumn{2}{|c|}{ The national linguistic consciousness of the British people } \\
\hline Jack & Jill \\
\hline $\begin{array}{l}\text { stereotypical thinking: } \\
\text { fairy tale character- social stereotype }\end{array}$ & $\begin{array}{c}\text { stereotypical thinking: } \\
\text { fairy tale character- social stereotype }\end{array}$ \\
\hline $\begin{array}{l}\text { stereotypical perception: } \\
\text { master, jack of all trades, nimble - national- } \\
\text { cultural stereotype image }\end{array}$ & $\begin{array}{c}\text { stereotypical perception: } \\
\text { well-bred spouse - national-cultural } \\
\text { stereotype image }\end{array}$ \\
\hline $\begin{array}{c}\text { stereotyped cognition: } \\
\text { social and cultural behavior stereotype }\end{array}$ & $\begin{array}{l}\text { stereotyped cognition: } \\
\text { gender behavior stereotype }\end{array}$ \\
\hline
\end{tabular}

\subsection{Stereotyped precedent names based on historical data}

There are some stereotyped precedent names in Kazakh like: "Қасым ханның қ̧асқ̧а жолье" (Direct road of Kasym khan), "Есім ханның ескі жол” (An old way of Esim khan), "Абылайдың асында шаппаванда, атаңңның басында шабасың ба?" (Where else will you ride except at the solemn remembrance of Abylai Khan?), and others. They are based on different historical events and occupy a mighty place in the memory of the people. For example, phraseostereotypes "Direct road of Kasym khan", "The disease of Esim Khan lasts four days" describe the concept of justice, tact, the right way, goodness with the ritualism law regulations of the Kazakh steppe in the XVI-XIX centuries. And phraseostereotype "Where else will you ride except at the solemn remembrance of Abylai Khan? " informs about the events that took place at the festive dinner dedicated to the spirit of Kazakh khan Abylai. Perhaps, the term Bilerkenesiwas formed according to Khan Kenesi, which was used earlier. Bilerkenesi 
came after Khan Kenesi, and ruled the country. The basic word of the complex word formation - kenes has been used since the middle Turkic time and denoted a "council" that ruled a country, keneshi was defined as a ruler's administrative office. Large meetings were called 'kenes' at Kazakh 'kaganat' times. For example, 'Kultobenin basynda kunde kenes' means a meeting which is held on Kultobe every day) (Bril'ova et al., 2004).

"Куда Макар телят не гонял" (Makar drove calves to the middle of nowhere), "Ha бедного Макара все шишки валятся" (роor Makar would fall on his back and break his nose; no butter will stick to his bread), "Шемякин суд” (Shemyakya'a court; unjust trial), and other phrase stereotypes in the Russian language show a fragment of the past life data of the Russian people. For example, Makar was a simple peasant who lived in the twentieth century. People said about him, "Makar is a poor landless peasant. He was forced to feed calves on distant pastures", (Bystrova, Shansky, 2007). As can be seen, the recurring story of Makar's daily routine was a common character of a common man in the consciousness and view of the Russian people and has an impact on the formation of the notion of a faraway, distant land. And Shemyakin court is a phraseostereotype which was formed in connection with the trial of Prince Dimitrium Shemayaka in an unjust, cruel way. Thus, we can meet conversation stereotype in the spoken language of the Russian people: "Эmo Сидорова правда, да Шемякин суд” (This is Sidor's truth and Shemyakya's trial) that means unjust, false, wrong actions.

There are national-cultural stereotypes in the English language like "Queen Anne is dead!", "Beau Brummell”(Krasnykh, 2012) and others, they are formed from anthroponyms Anne and Brummell. For example, "Queen Anne is dead!" is a conversational stereotype that the English people used to hear later in the event. In this example, Anne was a British queen, who ruled from 1702 to 1714. In the second example, Brummell (George Bryan Brummell) was the arbiter of men's fashion in Regency England, first men's fashion designer of the classic men's style clothes. His name has become a complete image of dandy, smart dresser, denoting something majestic and fashionable in the linguistic mind of the English people.

The national-cultural character of stereotyped precedent names in the Kazakh, Russian and English languages associated with historical data is given in the following tables.

Table 7: Stereotyped precedent names based on Kazakh historical data

\begin{tabular}{|c|c|c|}
\hline \multicolumn{2}{|c|}{ The national linguistic consciousness of the Kazakh people } \\
\hline Kasym khan & Esim khan & Abylai khan \\
\hline $\begin{array}{c}\text { stereotypical } \\
\text { thinking: } \\
\text { historical person - } \\
\text { social stereotype }\end{array}$ & $\begin{array}{c}\text { stereotypical thinking: } \\
\text { historical person - social } \\
\text { stereotype }\end{array}$ & $\begin{array}{c}\text { stereotypical thinking: } \\
\text { historical person- social } \\
\text { stereotype }\end{array}$ \\
\hline $\begin{array}{c}\text { stereotypical } \\
\text { perception: } \\
\text { individuality, justice } \\
\text { - national-cultural } \\
\text { stereotyped notion }\end{array}$ & $\begin{array}{c}\text { stereotypical perception: } \\
\text { ancestor tradition adherent } \\
\text { - national-cultural } \\
\text { stereotyped } \\
\text { cognition: }\end{array}$ & $\begin{array}{c}\text { stereotypical perception: } \\
\text { unity, peace - national- } \\
\text { cultural }\end{array}$ \\
$\begin{array}{c}\text { social and cultural } \\
\text { behavior stereotype }\end{array}$ & $\begin{array}{c}\text { stereotyped cognition: } \\
\text { stereotype-symbol }\end{array}$ & $\begin{array}{c}\text { stereotyped cognition: } \\
\text { social and cultural } \\
\text { behavior stereotype }\end{array}$ \\
\hline \multicolumn{2}{|c}{ stereotype } & \\
\hline
\end{tabular}

XLinguae, Volume 11, Issue 2, April 2018, ISSN 1337-8384, eISSN 2453-711X 
Table 8: Stereotyped precedent names based on Russian historical data

\begin{tabular}{|c|c|}
\hline \multicolumn{2}{|c|}{ The national linguistic consciousness of the Russian people } \\
\hline Makar & Shemyaka \\
\hline stereotypical thinking: & stereotypical thinking: \\
historical person- social stereotype & historical person- social stereotype \\
\hline stereotypical perception: & stereotypical perception: \\
a simple man - national-cultural stereotype & unjust, false, wrong-national-cultural \\
image; & stereotyped notion \\
far, distant land - national-cultural & \\
stereotyped notion & \\
\hline stereotyped cognition: & stereotyped cognition: \\
social-cultural stereotype & social-cultural stereotype \\
\hline
\end{tabular}

Table 9: Stereotyped precedent names based on British historical data

\begin{tabular}{|c|c|}
\hline \multicolumn{2}{|c|}{ The national linguistic consciousness of the English people } \\
\hline Anne & Brummell \\
\hline stereotypical thinking: & stereotypical thinking: \\
historical person- social stereotype & historical person- social stereotype \\
\hline stereotypical perception: & stereotypical perception: \\
past event - national-cultural stereotyped & dandy, smart dresser - national-cultural \\
notion & stereotype image \\
\hline stereotyped cognition: & stereotyped cognition: \\
social-cultural stereotype & social-cultural stereotype \\
\hline
\end{tabular}

\subsection{Stereotyped precedent names based on fiction}

We can relate "Myrkimbai", "Dairabai", "Sudir Akhmet", and other Kazakh anthroponyms to stereotyped precedent names formed on the basis of fiction works. For example, Myrkimbai and Dairabai are the heroes in the works of Beimbet Mailin (Beysukulov, 2007). They are reflected in a social stereotype image of the Kazakh society's reality of the twentieth century. Also the writer's story "The reason for the dispute is the Dairabai's cow" became a stereotyped linguistic figure in the Kazakh language, and was the basis to formation of the notion 'problematic story without any solutions'.

Sudir Akhmet is one of the characters of A.Z. Nurpeisov's (2010) novel Blood and Sweat. It can be stated that stereotype images of stupid, sycophant, tedious people appeared in the Kazakh language through his behavior.

Anthroponyms Oblomov (Goncharov, 2016) and Akaky Akakievitch (Gogol, 2006) were made by artistic works in the Russian language and they identify stereotype images. For example, Oblomov indicates a lazy, quitter person in bad social conditions, Akaky Akakievitch denotes a character of a simple, calm-natured person and a man who does not care about others' affairs.

In the English language King Charles, Mark Tapley are the main characters' names in C. Dikkens' (2015, 2009) novels David Copperfield (2015), Martin Chuzzlewit (2009), and John Bull is a character in J. Arbuthnot's (2012) pamphlet The History of John Bull. In this connection, the phraseostereotype "a King Charles's head" represents the notion of thoughts that cause headache, and drive to desperation, and Mark Tapleyis a man with high spirituality, who does not despair, despite endless difficulties, John Bull indicates the stereotype image of a judicious, exemplary, virtuous person.

The nature of the national-cultural stereotyped precedent names in the linguistic sense of Kazakh, Russian and English people is given in the following tables: 
Table 10: Stereotyped precedent names based on Kazakh fiction

\begin{tabular}{|c|c|c|}
\hline \multicolumn{3}{|c|}{ The national linguistic consciousness of the Kazakh people } \\
\hline Myrkimbai & Dairabai & Sudir Akhmet \\
\hline $\begin{array}{c}\text { stereotypical thinking: } \\
\text { artistic character - social } \\
\text { stereotype }\end{array}$ & $\begin{array}{c}\text { stereotypical thinking: } \\
\text { artistic character - social } \\
\text { stereotype }\end{array}$ & $\begin{array}{c}\text { stereotypical thinking: } \\
\text { artistic character - social } \\
\text { stereotype }\end{array}$ \\
\hline $\begin{array}{c}\text { stereotypical perception: } \\
\text { person in bad social } \\
\text { conditions - national- } \\
\text { cultural stereotype image }\end{array}$ & $\begin{array}{c}\text { stereotypical perception: } \\
\text { naive, guileless, simple } \\
\text { peasant- national-cultural } \\
\text { stereotype image }\end{array}$ & $\begin{array}{c}\text { stereotypical perception: } \\
\text { stupid, sycophant, tedious, liar - } \\
\text { national-cultural } \\
\text { stereotype image }\end{array}$ \\
\hline $\begin{array}{c}\text { stereotyped cognition: } \\
\text { social and cultural } \\
\text { stereotype }\end{array}$ & $\begin{array}{c}\text { stereotyped cognition: } \\
\text { social and cultural } \\
\text { behavior stereotype }\end{array}$ & $\begin{array}{c}\text { stereotyped cognition: } \\
\text { behavior stereotype }\end{array}$ \\
& & \\
\hline
\end{tabular}

Table 11: Stereotyped precedent names based on Russian fiction

\begin{tabular}{|c|c|}
\hline \multicolumn{2}{|c|}{ The national linguistic consciousness of the Russian people } \\
\hline Oblomov & Akaky Akakievitch \\
\hline $\begin{array}{l}\text { stereotypical thinking: } \\
\text { artistic character - social stereotype }\end{array}$ & $\begin{array}{l}\text { stereotypical thinking: } \\
\text { artistic character - social stereotype }\end{array}$ \\
\hline $\begin{array}{l}\text { stereotypical perception: } \\
\text { a lazy, quitter, unlucky person - national- } \\
\text { cultural stereotype image }\end{array}$ & $\begin{array}{c}\text { stereotypical perception: } \\
\text { simple, calm natured, simple-minded person } \\
\text { - national-cultural stereotype image }\end{array}$ \\
\hline $\begin{array}{c}\text { stereotyped cognition: } \\
\text { social and cultural behavior stereotype }\end{array}$ & $\begin{array}{c}\text { stereotyped cognition: } \\
\text { behavior stereotype }\end{array}$ \\
\hline
\end{tabular}

Table 12: Stereotyped precedent names based on British fiction

\begin{tabular}{|c|c|c|}
\hline \multicolumn{2}{|c|}{ The national linguistic consciousness of the English people } \\
\hline Mark Tapley & Charles & John Bull \\
\hline $\begin{array}{c}\text { stereotypical thinking: } \\
\text { artistic character - social } \\
\text { stereotype }\end{array}$ & $\begin{array}{c}\text { stereotypical thinking: } \\
\text { artistic character - social } \\
\text { stereotype }\end{array}$ & $\begin{array}{c}\text { stereotypical thinking: } \\
\text { artistic character - social } \\
\text { stereotype }\end{array}$ \\
\hline $\begin{array}{c}\text { stereotypical perception: } \\
\text { patient, simple-minded, } \\
\text { with high spirituality - } \\
\text { national-cultural } \\
\text { stereotypic image }\end{array}$ & $\begin{array}{c}\text { stereotypical perception: } \\
\text { tedious, confusing affair - } \\
\text { national-cultural stereotypic } \\
\text { image }\end{array}$ & $\begin{array}{c}\text { stereotypical perception: } \\
\text { judicious, exemplary, } \\
\text { virtuous person - national- } \\
\text { cultural stereotypic image }\end{array}$ \\
$\begin{array}{c}\text { stereotyped cognition: } \\
\text { behavior stereotype }\end{array}$ & $\begin{array}{c}\text { stereotyped cognition: } \\
\text { social and cultural stereotype }\end{array}$ & $\begin{array}{c}\text { stereotyped cognition: } \\
\text { social and cultural } \\
\text { stereotype }\end{array}$ \\
\hline
\end{tabular}

\section{Conclusions}

In conclusion, it can be stated that national-cultural stereotyped precedent names have their own value in the linguistic system. They are formed through national-cultural heritage and considered to be the main source of national mentality and national behavior data. They have functions according to their communicative description: a) evaluating; b) modeling (function of perception according to world image model); c) pragmatic (impact function); esthetic (function of esthetic perception of the world);d) code (mental-verbal function); e) euphemistic functions.

The national and cultural component in the content of the precedent names is related to the characterization of real historical figures and mythological characters. They carry cognitive information that is important to the nation. 


\section{Bibliographic references}

ALMETOVA, A.S. - PIRNAZAROVA, A.B. 2014. To develop linguacultural competence skills through pragmatic texts. In: News of Kazakh Ablai Khan University of International Relations and World Languages. Series "Pedagogical Sciences", n. 3, pp. 79-86. ISSN 2307-650X

ARBUTHNOT, J. 2012. The History of John Bull. In: Independent Publishing Platform, vol.17, pp. 342-351. ISBN-13:978-1475216288.

ARDAK, K. 2014. Whereever you go. Available online: http://www.massaget.kz/blogs/9882/.

ASHIMHANOVA, F.M. 2007. Linguoculturological study of anthroponyms in the Kazakh language: PhD Thesis. Almaty. Registration: 0407PK00442.

BEYSUKULOV, T.A. 2007.SaryarkaSangla. Dedication to prominent public figure, poet, writer, publicist, playwright Beimbet Mailin. Almaty: The scientific and biographical series "The Great Persons". ISBN 9965-473-98-6

BOGOYAVLENSKAYA, Y.V.- NAKHIMOVA, E.A.-CHUDINOV, A.P. 2016. Precedent utterances in the national historical memory. In: Cognitive Linguistics, n. 2, pp. 39-49. ISSN 1877-9751.

BOKEEV, O. 1990. Man-deer: Novelettes and short stories. Moscow: Izvestiya. ISBN 5-206-00059-0.

BRIL'OVA, I.S. - VOLSKAYA, N. - ZAKHARENKO, I. - KRASNYKH, V. GUDKOV, D. 2004. Russian Cultural Space. Moscow: Gnozis. ISBN: 5-94244-0034, 978-5-94244-003-9.

BUDAEV, E.V. - CHUDINOV, A.P. 2017. Transformations of the precedent text: "Metaphors We Live By" in the scientific discourse. In: Cognitive Linguistics, vol. 1, n. 50, pp.60-67. ISSN 1877-9751.

BYSTROVA, E. - SHANSKY, N. 2007. Phraseological Dictionary of Russian language. Moscow: AST. ISBN: 5-17-040745-9.

CHULKOV, S. - POLYAKOVA, V. 1988.Russian proverbs and sayings. Moscow: Khudozhestvennaya Literatura. ISBN: 5-280-00027-2.

DIKKENS, C. 2009. Martin Chuzzlewit. Oxford: Oxford University Press. ISBN-10: 0199554005.

DIKKENS, C. 2015. David Copperfield. Oxford: Publishing Platform. ISBN-10: 1517337666.

ERMERS, R. 2017. Honor Related Violence A New Social Psychological Perspective. Holland: Rutledge. ISBN-10: 1138749192.

ESENBERLIN, I. 2005. Koshpendiler. Almaty: Esenberlin Foundation. ISBN 9965609-13-6.

FROLOVA, O.N. 2009.National and cultural specificity of the stereotype: $\mathrm{PhD}$ Thesis. Moscow. Available online: http://www.dissercat.com/content/natsionalnokulturnaya-spetsifika-stereotipa-na-materiale-nemetskogo-yazyka.

GOGOL, N.V. 2006.The Overcoat. The Petersburg Stories. Moscow: Martin. ISBN: 5-8475-0365-2.

GOLUBEVA, N.A. 2016. Syntactic precedent units in religious discourse. In: Cognitive Linguistics, vol. 1, n. 46, pp.91-100. ISSN 1877-9751.

GOLUBEVA, N.A. 2017. The precedent function of the imperative in religious discourse. In: Cognitive Linguistics, n. 1, vol. 50, pp.68-75. ISSN 1877-9751.

GONCHAROV, I.A. 2016.Oblomov. Moscow: Azbuka. ISBN: 978-5-389-10475-4.

GRITSENKO, L.M. 2009.Language game as a way of realization of the precedent text in chat-communications. In: Bulletin of Tomsk State University, n. 318, pp. 1417. Available online: http://journals.tsu.ru/uploads/import/831/files/318-014.pdf.

GUDKOV, D.B. 2004.Toward the dictionary of precedent phenomena. Moscow: Languages of Slavic Culture. ISBN: 5-94457-178-0.

HOUGHTON, S.A. 2014. Researching the Stereotypes of People around Me. Cambridge: Cambridge Scholars Publishing. ISBN (10): 1-4438-6540-0. 
IBRAHIM, W.F. - DARWISH, R.E. 2013. Spheres-sources of precedent names in Russian and Egyptian press. In: Cognitive Linguistics, n. 4, vol. 37, pp.92-99. ISSN: $1812-3228$.

ISSERS, O.S. 2017. "The right to be a father": a linguistic cognitive analysis of the stereotypes of Russian society of fathers' rights and duties. In: Cognitive Linguistics, n. 3, vol. 53, pp.37-50.ISSN 1877-9751.

KONDRATIEVA, T.N. 1983. Metamorphoses of one's own name: experience of a dictionary. Kazan: Kazan State University Press. Available online: https://www.twirpx.com/file/2060878/

KOPEIULY, M. 2010. Kazak shezhiresi. Almaty: El Shezhire. ISBN 9786017011925. KRASNYKH, V.V. 2003. "Insider" among the "strangers" - Myth or reality? Moscow: ITDGK "Gnosis". ISBN: 5-94244-004-2.

KRASNYKH, V.V. 2012. Ethnopsycholinguistics and linguoculturology: a course of lectures. Moscow: ITDGK "Gnosis". ISBN: 5-94244-009-3.

LADEGAARD, H. 2011. Stereotypes in the making prejudice and cultural generalizations in Hong Kong students' discourse. In: Journal of Asian Pacific Communication, vol. 21, n. 1, pp. 133-158. ISSN 0957-6851.

MAGAYIN, M. 2004. Kokbalak. Almaty: Atamura. ISBN: 9789965341359.

NAGORNAYA, A.V. 2017. The precedent name as a means of conceptualizing events in contemporary English. In: Psycholinguistics, n. 2, pp. 109-123. ISSN: 15736555.

NURPEISOV, A.Z. 2010. Blood and Sweat. Moscow: Khudozhestvennaya Literatura. ISBN: 9785280034891.

ORLOVA, O.V. - KABANKOV, A.I. 2015. The Dynamics of a Creative Personality's Precedent-related World in the Discourse of New Media: Statement of the Problem. In: Siberian Philological Journal, n. 4, pp. 182-187. ISSN 1813-7083.

ORLOVA, O.V. - KABANKOV, A.I. 2017. Regulativity of precedent text in the internet discourse. In: Siberian Philological Journal, n. 2, pp. 271-278. ISSN 18137083.

ORLOVA, O.V. 2013. "Eternity smells of petroleum" as a precedent text of modern culture in the Internet discourse. In: Siberian Philological Journal, n. 2, pp. 250-257. ISSN 1813-7083.

OXFORD DICTIONARY OF ENGLISH. 2010. Oxford: Oxford University Press. ISBN-10: 0199571120, ISBN-13: 978-0199571123.

PROKHOROV, Y.E. 2008.National socio-cultural stereotypes of verbal communication and their role in teaching Russian to foreigners. Moscow: Librokom. ISBN: 978-5-397-00860-0.

RASPAEVA, G. 2017. The Christian Precedent Phenomena in L. N. Tolstoy's Novel "Resurrection". In: Rupkatha Journal on Interdisciplinary Studies in Humanities, vol. 9, n. 2, pp.129-136. ISSN 0975-2935.

REMBISZEWSKA, D.K. 2010.Kategoriaswój - obcy w antroponimiilokalnejnaprzykładzienazwiskmieszkańcówWysokiegoMazowieckiego.

In: Acta Baltico-Slavica, n. 34, pp. 169-184. ISSN: 0065-1044.

SHCHUKLINA, T.Y. 2017.Precedent phenomena as the source of non-usual wordformation in the contemporary Russian mass media. In: Przeglad Wschodnioeuropejski, vol. 8, n. 1, pp.209-217. ISSN: 2081-1128.

SHEBALOV, R.Y. 2004.Onomastic game in the artistic text. Abstract of $\mathrm{PhD}$. Yekaterinburg. Available online: http://www.dissercat.com/content/onomasticheskaya-igra-v-khudozhestvennomtekste-na-materiale-rannikh-rasskazov-ap-chekhova.

SIMPSON, J. - SPEAKE, J. 2008. The Oxford Dictionary of Proverbs. New York: Oxford University Press. ISBN-13:9780199539536 
SMAGULOVA, K.N. 1998. National-cultural aspects of synonymic phraseological units: PhD Thesis. Almaty. Registration: 0599PK00011.

TENORIO, E.H. 2000.Gender, Sex and Stereotyping in the Collins Cobuild English Language Dictionary. In: Australian Journal of Linguistics, vol. 20, n. 2, pp. 211-230. ISSN: 0726-8602.

TURLYBAEVA, A. 2010.Akbata. Almaty: Ener. ISBN: 5898404511.

YURINA, E.A. - BOROVKOVA, A.V. 2015. Precedent figurative words and expressions in the Dictionary of Russian Food Metaphors. In: Russian Journal of Lexicography, vol. 1, n. 7, pp. 36-52. ISSN 2311-3758.

Words: 6504

Characters: 46402 (25,78 standard pages)

PhD student Aigul Murzinova,

Department of Theory and Methodology of Kazakh Linguistics,

Kazakh State Women's Teacher Training University

99 Aiteke-Bi Str.

050000, Almaty,

Kazakhstan

Ai.msai2013@mail.ru

Prof. Altynay Tymbolova, Doctor of Sciences (Philology)

Dean of the Faculty of Kazakh Philology and World Languages

Kazakh State Women's Teacher Training University, 99

Aiteke-Bi Str.,

050000, Almaty

Kazakhstan

Al.tymbolova@mail.ru

PhD student Kalima Yelshibaeva,

Department of Theory and Methodology of Kazakh

Linguistics,

Kazakh State Women's Teacher Training University

99 Aiteke-Bi Str.,

050000, Almaty

Kazakhstan

K.kelshibaeva@mail.ru

Assoc. Prof. Gulmira Abdirassilova, Candidate of Sciences(Philology)

Department of Theory and Methodology of Kazakh

Linguistics,

Kazakh State Women's Teacher Training University

99 Aiteke-Bi Str.,

050000, Almaty

Kazakhstan

GAb.gulmira@mail.ru

Senior Lecturer Ainur Kushkimbayeva, PhD of Sciences(Philology),

Department of Theoretical and Applied Linguistics

Aktobe State Regional University named after K.Zhubanov,

7 Grishina Str.,

Aktobe

Kazakhstan 
Ainur_Alitok@mail.ru

Assoc. Prof. MukhtarMirov, PhDof Sciences (Philology)

Department of Theoretical and Applied Linguistics

Aktobe State Regional University named after K.Zhubanov

7 Grishina Str.,

Aktobe

Kazakhstan

Mukhtar_mirov-agu@bk.ru 